\title{
Article \\ Digital Transformation and Strategy in the Banking Sector: Evaluating the Acceptance Rate of E-Services
}

\author{
Fotis Kitsios*(D), Ioannis Giatsidis (D) and Maria Kamariotou (D) \\ Department of Applied Informatics, University of Macedonia, GR54636 Thessaloniki, Greece; \\ mai17055@uom.edu.gr (I.G.); mkamariotou@uom.edu.gr (M.K.) \\ * Correspondence: kitsios@uom.gr
}

Citation: Kitsios, F.; Giatsidis, I.; Kamariotou, M. Digital Transformation and Strategy in the Banking Sector: Evaluating the Acceptance Rate of E-Services. J. Open Innov. Technol. Mark. Complex. 2021, 7, 204. https://doi.org/10.3390/ joitmc7030204

Received: 25 August 2021

Accepted: 16 September 2021

Published: 21 September 2021

Publisher's Note: MDPI stays neutral with regard to jurisdictional claims in published maps and institutional affiliations.

Copyright: (c) 2021 by the authors. Licensee MDPI, Basel, Switzerland. This article is an open access article distributed under the terms and conditions of the Creative Commons Attribution (CC BY) license (https:/ / creativecommons.org/licenses/by/ $4.0 /)$.

\begin{abstract}
Digital transformation in the banking sector is a continuous process that affects both the external and internal environment by redesigning internal processes and existing methods. There are many reasons that digital transformation takes place, such as servicing remote areas without physical branches, differentiation from competitors or reduction of operating costs. In any case, there are a lot of doubts about the acceptance of digital technologies. Thus, this article examines the acceptance rate of digital transformation in the banking sector in Greece. One hundred and sixty-one employees at Greek banks completed the survey. A Multivariate Regression Analysis was implemented to analyze the items of the Technology Acceptance Model. The findings of this paper indicate the perception of bank employees with regard to new technologies. This paper provides a practical contribution for executives of Greek banking organizations to schedule targeted educational programs to facilitate the transition to the new digital era for their employees. Executives are curious if employees are ready to accept and implement digitalization in their daily job routine. Therefore, the Technology Acceptance Model can provide answers to executives in facing these challenges.
\end{abstract}

Keywords: digital strategy; digital transformation; digital banking; technology acceptance model; e-services; user's intention; business model

\section{Introduction}

The modern, ever-changing technological environment forces all economic units to undergo digital transformation. Digital transformation has dual functions in that it enables banking organizations to offer new service channels through new electronic platforms (e-banking, virtual banking) and service points (e-branch stores, POS) and also reduces their operating costs by limiting the number of physical stores and staff that they use [1,2]. This is the reason that, according to [3], the banking industry worldwide spends three times more money on IT investments than any other industry as a whole. Business models are under scrutiny in the banking industry. Digitalization, disruptive innovation and new technologies are changing traditional business models and processes. As a result, banks must adapt their business models to change how they interact with customers, manage their middle and back-office operations, be competitive and be ready for the future [4].

For [5], digital transformation is identified as "the process that aims to improve a unit by bringing about essential changes in its structure through combining information, information technology, communications, and connectivity technology." According to [6], the digital transformation includes a broad concept of banking, namely: digitization of documents, an electronic signature for transactions, e-learning, teleconference, online trading platforms, digital stores, e-statements and m-payments. Customers are increasingly using digital disruptions, and new types of solutions are emerging in this sector. Thus, new business models are essential in the banking industry to spotlight all significant banking processes.

The transition to e-banking, however, is the result of other equally important factors, which include the need for banks to adapt to the new technological data of the time, to 
offer an additional service channel, to deregulate the banking market and to allow the entry of other companies (e.g., Alipay, Paypal) to intensify competition [7,8]. Ref [9] used the term "open point of banking" to describe all non-banking companies offering products and services similar to banking. Half of the population in their research was receptive to using such products.

A significant number of banking transactions are now carried out on most people's computer or mobile phone. The plethora of possibilities, plus the saving of time and cost, and the ease of use of these applications constantly grants them a share of conventional banking channels (bank branches). Also, through these applications, the owners-customers are allowed to have real-time information about the valuation of their investment products, the banks' reward programs and the expenses they have incurred through digital media to receive more favorable tax treatment. The aforementioned benefits make mobile banking more and more attractive not only for younger people but for all smartphone owners [10-18]. For the same reasons, ref [19] uses the term "digital natives" to describe those born after 1980 who have a high degree of familiarity with and acceptance of new electronic technologies.

This is why the administrations of Greek banks are investing significantly large amounts in e-banking infrastructure, amounts that are expected to depreciate very quickly due to the degree of acceptance of these technologies by bank customers and the saving of resources through the restriction of conventional banking. The penetration of electronic means of banking transactions is now part of the culture of banks. There are, of course, people who disagree with this. According to [20], the shrinking of natural bank branches and the adoption of digital alternatives, though they cut costs, are not profitable. Investigating the effectiveness of IT service channels, they concluded that, along with the costs, revenue growth opportunities are lost when bank branches close.

In any case, it is generally accepted that digital banking enables residents of underdeveloped areas to have access to banking services, as no investment or infrastructure is required from banks [6,21]. According to [22], the digitalization of banking offers multiple benefits for both organizations (banking institutions) and their customers. Banks using digital technologies save time, reduce operating costs and optimize monitoring, risk management and control methods, as well as being able to offer products and services in the market with improved quality. Customers using digital banking services can reduce the time between transactions and complete them securely. Banking services are made accessible to people living in remote areas without the physical presence of the banks; differentiation of competition, stores and services are operated with a smaller number of employees, reduction of operating costs and standardization of internal processes [23].

The COVID-19 has firmly impacted the Greek economy. In addition to the recession of the economy and increase in the NPE ratio, COVID-19 has also driven the rapid digitalization of Greek banks and changes in business models. Nowadays, $40 \%$ of bank employees work remotely (at home), and many processes in banking branches are completed through electronic means. For instance, the majority of the work force in central units (not retail branches) work at home, making use of means such as Cisco jabber and the Webex platform. Moreover, due to COVID-19, it is nowadays acceptable for a customer to send an email to execute an order. Previously, apart from e-banking and phone banking, the customer would be required to visit a retail branch. The post-COVID world will bring new challenges and opportunities and an accelerating trend for digitalization.

In the present study, the degree of acceptance of digital transformation by bank employees is analyzed through empirical research. The data were collected with questionnaires given to 161 employees of banking institutions operating in Greece and participating in the Federation of Banking Employees of Greece (OTOE). The crucial questions raised in this study are: are bank employees ready to accept and implement the digitization of banking in their daily lives? Do they know the effect that digitalization can have on the future of their work? Is their attitude towards digitization influenced by fear of losing their 
job or by other factors? In an industry that is constantly shrinking, is digital banking a threat to job loss or a stronghold for job security?

The Greek financial system was put into a deep recession due to the financial crisis of 2008, due to the PSI of government debt and the lack of profitability of Greek banks. As the Greek economy was influenced by most of the other European economies, we focused on Greece. Greek banks have fulfilled many restrictions and taken significant steps to meet European standards (EBA). In this direction, we searched for the influence of the digitalization of the Greek banking system (not only the usage of e-banking) but mainly the impact of digitalization of the work among bank employees.

The contribution of the paper is twofold. First, it adds value and contributes to existing academic knowledge for future researchers to find suitable ground and structure their research on existing findings. There are not enough data on the degree of acceptance of digital transformation by the staff of Greek banks. However, as a concept, it concerns greatly both the administrations of Greek banks and the secondary trade union body of bank employees, OTOE. Second, this paper can be a valuable guide to the management of banks. These findings can help the Human Resources Divisions of financial institutions adjust their personnel management policies based on research data to mitigate the negative effects of digitizing work, and, at the same time, build educational and training programs that can aid the smooth transition of employees to the new digital age. For banks' administrations, reading how employees perceive their digital transformation creates an additional advantage in bargaining between employers and participating in the OTOE.

The following is the structure of the paper. Section 2 includes the theoretical background. The methodology is represented in Section 3, and Section 4 discusses the outcomes of the analysis. Section 5 presents limitations and avenues for future researchers.

\section{Materials and Methods}

The digital transformation of banks has two sides. The first one affects the customer base of banking institutions by offering new products, immediacy in transactions and banking presence $24 / 7$ even in areas without a natural banking presence. The second one significantly influences their human resources. In the case of the customer base, the benefits are easily perceived through empirical papers on the use of new technologies e.g., e-banking, m-banking and, in the case of their impact on banks' staff, the existing academic research has not covered a significant aspect of this topic. Commonly, most of the up-to-date analyses on the subject are in financial investigations and forums.

For many researchers, the term digital transformation is used in new digital trading channels such as e-banking, m-banking and e-branch. Few have associated it with the degree to which the banks' staff accept it and describe the opportunities or threats it creates or influences. As digital transformation is a relatively new concept in the banking sector, the relevant reports focus mainly on the degree of acceptance and usage of new technologies by users of e-banking applications, whether they are customers or bank employees. The first interesting reference is made in 1927 in an article in The Australian Banker [24], which shows the extent to which workers and their trade unions accepted the technological developments of that time in the banking industry. Characteristically, it is stated that when the old manuscripts were replaced with a computer printer, there was a portion of conservative employees who strongly opposed the innovation. As reported in 1930 by a Queensland banker [24], those bank employees who would not adapt to the new requirements of the time were either moved to smaller rural stores or, even worse, were at risk of losing their jobs.

Similarly, as early as 1933, there was the first reference [24] to trade union resistance to the Federal Council in adopting the technological innovations of the time, as they feared a reduction in jobs. In 1962, when the first computer was introduced to the State Savings Bank of Victoria, the trade union workers were the first to accept it without resistance. They actively supported the adoption of the digital transformation of that time. It is crucial to 
indicate that the employees adopted the innovation of the time, and they were compensated with shorter working hours and additional annual leave.

As the next decade brought new technological advances (on-line terminals in cash registers and universal computer use), joint consultation between employers and unions became imperative. In this regard, joint committees were set up for the smoothest possible transition of bank employees to the new era. Comparing the above with the developments in the Greek banking market of 2019, there are many similarities. The most common aspect is the early reaction of employees to new technologies due to fear of change [25] and the risk of losing their jobs.

Most previous studies reflect the attitude of bank staff towards digital transition. By grouping their results into the main idea and the determinants that influence the acceptance of digital transformation by employees, the following basic concepts are recorded: change, Technology Acceptance Model (TAM), e-banking, employees' skills and strategy. A key factor in accepting the digital transition, as in any new and different case, is change management [26]. Employers' responsibility is to properly prepare for a culture of change [27] to mitigate possible adverse reactions that will jeopardize the new venture's success [25]. A common denominator in most surveys is TAM and the key variables that make it up, which are perceived ease of use, perceived usefulness and self-perceived effectiveness (perception of one's ability to use the resources of new technology efficiently) [28]. The rate at which TAM variables affect the degree of acceptance is presented in subsequent sections.

In many studies (mainly of previous years), the concepts of digital transformation and e-banking are confusing. As the term digitization includes a much larger scope of work and is not exclusively a simple platform for banking transactions, the concepts should be separated. However, it is reasonable for e-banking users to be more receptive to technological change [29]. In every important issue that the management of an organization has to manage (especially in the banking space, where digital transition affects the way a vast number of staff work), a systematic approach and the preparation of a structured action plan within the organization are required [30].

The most critical factor in adopting change is the attitude of employees [25]. Whether acting autonomously or being motivated by their trade unions, their attitude towards change also determines the degree of success or failure of any venture they consider as risking their employment status quo. Many articles related to the digitalization of banking work record the need to train employees on how to use new technologies [31]. Often, employees, although willing to accept change, find it difficult to change, either because of lack of knowledge or skills required to implement the change. It is essential to have the proper training and education programs for employees, which, in addition to practical knowledge, also enable their gradual assimilation of and acclimatization to the new data of change.

Many scholars and practitioners have been paying attention to the banking sector, and factors affecting the development of new services have been analyzed [32-36]. Unbranched e-banking is related to the creation of digital financial transactions existence of bank branches and their workers. Digital transformation is a new process establishing a new age in the financial sector. The introduction of branchless banking has necessary implications that impact business workers. Amid significant technological investments in technology, there are no results supporting changes in banking efficiency for workers [37].

Researchers use perceived ease of use to define the degree of comprehension of the consumers of the new, branchless banking network. The key factors affecting perceived facility of use are self-efficacy of the computer (the degree to which a person believes that he can perform a task using a computer), computer anxiety (the degree that a person is afraid to use a computer), playfulness (the degree of pleasure associated with the use of a computer) and perception of external control (the degree to which a person thinks the resources of an organization are available to carry out its work) [38]. According to [39], the perceived ease of use affects digital banking significantly. However, the practice harms the embracing of online banking [40]. Other considerations should be taken into account as 
researchers examine Wireless Banking approval [39], in addition to perceived ease of use and perceived usefulness (as defined in the TAM model).

Researchers use perceived usefulness to define the degree to which the emerging technology can assist users in completing a mission. The key factors impacting the term perceived utility are viewed as ease of use, picture (the pace at which technology is used in order to improve its role and prestige), its users, its importance to work (the extent to which the user believes that modern technology relates to his work) and the quality of the end product (output level). The use of technology promotes the outcome and the visibility of the development (the degree to which the result is for technology users and the effect is visible) [38]. The perceived utility has no significant impact on digital banking acceptance [39]. Conversely, ref [41] inferred that, considered in comparison to perceived ease of use, usefulness is $50 \%$ more significant. Ref [40] stated that job relevance positively influences perceived utility. Experience, however, has an adverse incidence. Perceived self-efficacy describes how a person sees himself or herself as having the capability to make good use of the advantages of modern technology. This explains someone's firm belief in it must carry out its mission. Finally, ref [39] concluded that perceived self-efficacy has no substantial impact on the acceptance of digital banking.

Based on the review of the above studies [39,40,42], four hypotheses are drawn up to analyze the association between the following variables: usage behavior, perceived usefulness, perceived self-efficacy, perceived ease of use and intention to use.

Hypothesis 1 (H1). Perceived Usefulness positively impacts Intention to use digital banking.

Hypothesis 2 (H2). Perceived Ease of Use positively impacts Intention to use digital banking.

Hypothesis 3 (H3). Perceived Self-Efficacy positively impacts Intention to use digital banking.

Hypothesis 4 (H4). Intention to use digital banking positively impacts Usage behavior.

Figure 1 presents the theoretical framework.

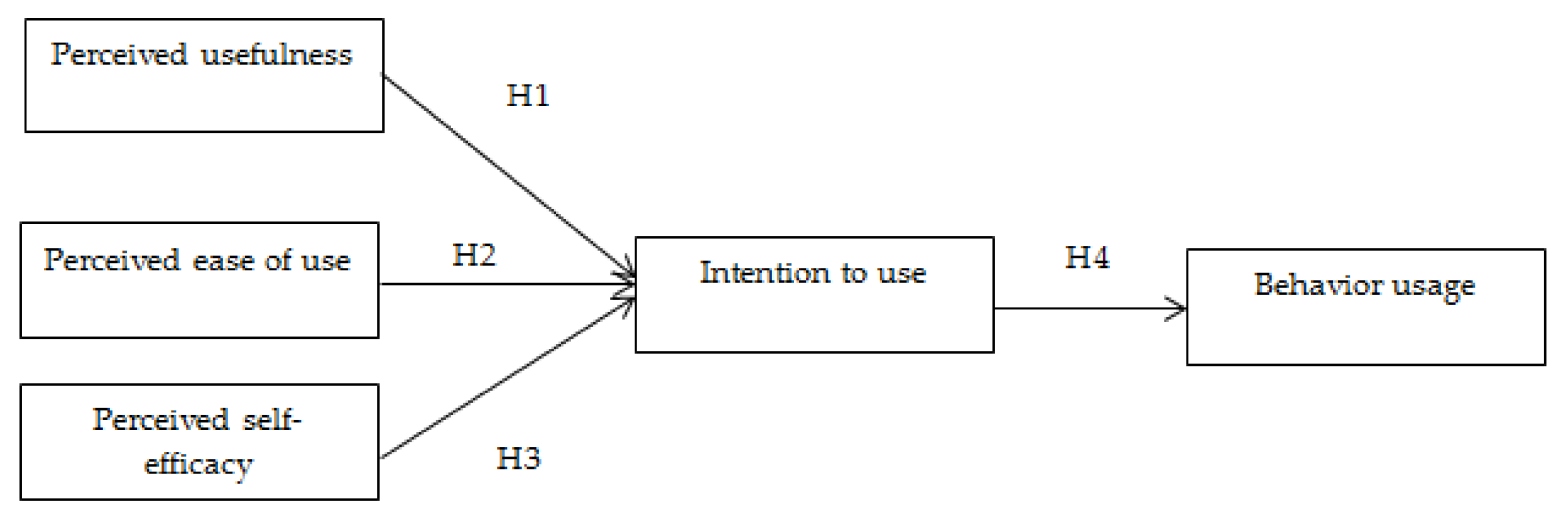

Figure 1. Theoretical framework.

\section{Methodology}

The study was based on the TAM $[43,44]$ and was applied to bank employeesmembers of the Federation of Banking Employees of Greece (OTOE) - using an on-line questionnaire. The questionnaire was administered to all bank executives of all levels. It would be misleading to have outcomes either only from the high level executives (they might present digitalization as a virtue for the banking system) or only from the low level employees (they might present digitalization as a vice). To represent the standard view, we choose not to concentrate on a specific level. 
The questionnaire used a five-point Likert-scale (Disagree-Agree) to measure five variables: usage behavior, perceived usefulness, perceived self-efficacy, perceived ease of use and intention to use. The instrument was based on similar research $[39,40,45,46]$ which focuses on the extent of acceptance of new technologies in the banking industry, both by staff and by end-users. Table 1 presents the items of the questionnaire for each variable.

Table 1. Questionnaire items and variables.

\begin{tabular}{ll}
\hline \multicolumn{1}{c}{ Variables } & \multicolumn{1}{c}{ Questions } \\
\hline & The use of digital banking applications or systems improves \\
the quality of my work & The use of digital banking applications or systems makes \\
my job more regulated & The use of digital banking applications or systems helps me \\
complete my tasks faster & The use of digital banking applications or systems supports \\
essential aspects of my work & The use of digital banking applications or systems increases \\
my productivity at work & The use of digital banking applications or systems enhances \\
my efficiency at work & The use of digital banking applications or systems allows \\
Perceived usefulness & me to conduct more work than would otherwise be possible \\
The use of digital banking applications or systems increases & my work effectiveness \\
The use of digital banking applications or systems simplifies \\
my work \\
Overall, I think that digital banking applications or systems \\
are helpful for my work in general
\end{tabular}

I consider it difficult to use automated digital banking applications or systems

It is easy for me to learn how to run digital banking applications or systems Interaction with digital banking systems or applications is always challenging

I find digital banking applications or systems easy to use to do what I want to do

Digital banking applications or systems connect rigidly and

Perceived ease of use inflexibly

I can easily recall how to execute my tasks using digital

banking applications or systems

The interaction with digital banking applications or systems requires a great deal of mental effort

My experience with digital banking applications or systems is transparent and understandable

I think it takes a great deal of effort to use digital banking

applications or systems in general

I think digital banking applications or systems are easy

to use

I could perform my duties with digital banking applications or systems ...

... if there was nobody around to tell me what to do when I

Perceived self-efficacy went

... if I just had a built-in assistance facility

... if someone taught me how to do this first

... if I had used similar applications to do the same job

before this one. 
Table 1. Cont.

\begin{tabular}{lll}
\hline Variables & \multicolumn{1}{c}{ Questions } & \multicolumn{1}{c}{ References } \\
\hline \multirow{3}{*}{ Intention to use } & If I had access to digital banking applications or systems, I \\
& would use them $\begin{array}{l}\text { If I had access to digital banking applications or systems, } \\
\text { then I foresee using them } \\
\text { Over the next }<\mathrm{n}>\text { months, I plan to use digital banking } \\
\text { applications or systems }\end{array}$ \\
\hline Usage behavior & $\begin{array}{l}\text { On average, how much time do you spend every day on } \\
\text { using digital banking applications or systems? }\end{array}$ \\
\hline
\end{tabular}

\section{Results}

The most significant percentage of the study's respondents belongs to the age group of $36-45(58.7 \%)$. The above is considered completely normal because the last mass recruitments in the industry took place in 2007-2008 due to the economic crisis in Greece. Respectively, it is particularly noteworthy that few belong to the age category $>56$ years. Due to targeted voluntary exit programs, employees over 55 years old had a particularly significant financial incentive to use voluntary exit programs. The survey found a small predominance of female employees ( $54.2 \%$ versus $45.8 \%$ ). The vast majority of respondents (85\%) hold Academic/Postgraduate/Doctoral degrees. Only 15\% of the respondents do not have an academic degree.

Those who responded to the survey are employed in 20 different units-objects of employment. The majority of the respondents work in the store network (45.8\%), while a significant percentage (10.3\%) manage red loans (unsecured claims). About $11.6 \%$ are in centralized services that support other units, while about $5.2 \%$ are in insurance services.

Regarding the respondents' banking work experience, there is a concentration in the age groups of $11-15$ and 16-20, whose population cumulatively reaches $60 \%$. It is noteworthy that there is a group, composing $11.6 \%$ of the study population, who have experience of $0-5$ years. Almost all of these employees are employed in units such as ITInformatics, HR and Internal Audit, and almost no one is employed in the branch network.

Based on Figure 1, two models were created in order to implement Multivariate Regression Analysis to analyze the data. In the first model, the independent variables are perceived usefulness, perceived ease of use and perceived self-efficacy, and the dependent variable is the intention to use. In the second model, the independent variable is the intention to use, and the dependent variable is usage behaviour. The reliability was measured using Cronbach's alpha, and the values ranged from 0.860 to 0.911 , exceeding the minimally recommended level of $0.70[49,50]$. These values are displayed in Table 2.

Table 2. Reliability analysis of the questionnaire items.

\begin{tabular}{cc}
\hline Variables & Cronbach $\alpha$ \\
\hline Perceived usefulness & 0.860 \\
Perceived ease of use & 0.863 \\
Perceived self-efficacy & 0.881 \\
Intention to use & 0.866 \\
Usage behavior & 0.911 \\
\hline
\end{tabular}

Pearson's correlation was implemented to explore the correlation among the dependent and independent variables [51-54]. Table 3 displays the values of Pearson's correlation analysis. 
Table 3. Correlation matrix.

\begin{tabular}{cccccc}
\hline & $\begin{array}{c}\text { Perceived } \\
\text { Usefulness }\end{array}$ & $\begin{array}{c}\text { Perceived Ease } \\
\text { of Use }\end{array}$ & $\begin{array}{c}\text { Perceived } \\
\text { Self-Efficacy }\end{array}$ & Intention to Use & Usage Behavior \\
\hline Perceived usefulness & 1.000 & 0.798 & 0.652 & 0.766 \\
Perceived ease of use & 0.798 & 1.000 & 0.718 & 0.741 & 0.651 \\
Perceived self-efficacy & 0.652 & 0.718 & 1.000 & 1.000 & 0.573 \\
Intention to use & 0.766 & 0.741 & 0.651 & 0.573 & 1.000 \\
Usage behavior & & & & & \\
\hline
\end{tabular}

Regarding the first model, Table 4 presents that $R^{2}$ is 0.648 and adjusted $R^{2}$ is 0.641 . These values indicate that $64 \%$ of the variance in success is described by independent variables. The $\mathrm{F}$ statistic is 96.191 with 161 degrees of freedom ( 3 from the regression and 158 from residuals), and the significance value is less than $p<0.05(0.000)$. Therefore, the model is significant. Regarding the second model, Table 4 presents that $R^{2}$ is 0.648 and adjusted $R^{2}$ is 0.641 . These values indicate that $32 \%$ of the variance in success is described by independent variables. The F statistic is 77.677 with 161 degrees of freedom ( 2 from the regression and 159 from residuals), and the significance value is less than $p<0.05$ (0.000). Consequently, the regression model does not predict intentional usage better, since the explanatory power of the regression does not exceed $50 \%$. The findings of regression analysis in Table 5 also confirm the prediction performance of the regression models.

Table 4. Regression analysis.

\begin{tabular}{cccccc}
\hline Model & $\mathbf{R}$ & $\mathbf{R}^{\mathbf{2}}$ & Adjusted $^{\mathbf{2}}$ & Estimate Standard Error & Durbin-Watson \\
\hline 1 & 0.805 & 0.648 & 0.641 & 0.525 & 2.141 \\
2 & 0.573 & 0.328 & 0.324 & 0.833 & 1.949 \\
\hline
\end{tabular}

Table 5. ANOVA statistics of regression.

\begin{tabular}{|c|c|c|c|c|c|c|}
\hline Model & & Sum of Square & Df & Mean Square & $\mathbf{F}$ & Sig. \\
\hline \multirow[t]{3}{*}{1} & Regression & 79.587 & 3 & 26.529 & 96.191 & 0.000 \\
\hline & Residual & 43.299 & 158 & 0.276 & & \\
\hline & Total & 122.886 & 161 & & & \\
\hline \multirow[t]{3}{*}{2} & Regression & 53.979 & 2 & 53.979 & 77.677 & 0.000 \\
\hline & Residual & 110.493 & 159 & 0.695 & & \\
\hline & Total & 164.472 & 161 & & & \\
\hline
\end{tabular}

Based on the results presented in Table 6 and Figure 2, the beta value of perceived usefulness was 0.444 with a significance level of 0.000 . Thus, perceived usefulness has a positive and significant impact on intention to use, and H1 was supported. The beta value of perceived ease of use was 0.264 with a significance level of 0.005 . Thus, perceived ease of use has a positive and significant effect on intention to use, and $\mathrm{H} 2$ was supported. The beta value of perceived self-efficacy was 0.172 with a significance level of 0.026 . Thus, perceived self-efficacy has a positive and significant effect on intention to use, and $\mathrm{H} 3$ was supported. The beta value of intention to use was 0.573 with a significance level of 0.000 . Thus, perceived intention to use has a positive and significant impact on usage behavior, and $\mathrm{H} 4$ was supported. 
Table 6. Hypothesis testing.

\begin{tabular}{ccccc}
\hline Model & $\boldsymbol{\beta}$ & $\mathbf{t}$-Value & Sig. & VIF \\
\hline Perceived usefulness & 0.444 & 5.547 & 0.000 & 2.853 \\
Perceived ease of use & 0.264 & 3.027 & 0.005 & 3.384 \\
Perceived self-efficacy & 0.172 & 2.482 & 0.026 & 2.139 \\
Intention to use & 0.573 & 8.813 & 0.000 & 1.000 \\
\hline
\end{tabular}

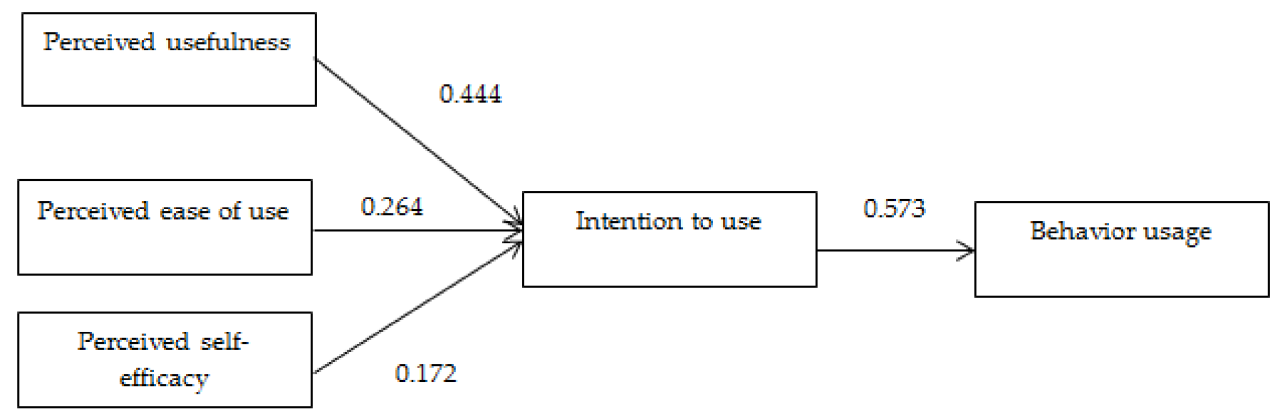

Figure 2. Results for direct effects.

The outcomes of this paper prove that the majority of the respondents agree that digitization allows them to carry out a larger volume of work in a shorter time and more easily. Regarding perceived ease of use, a significant percentage of the respondents consider that familiarity with new technologies does not require special knowledge and skills. As expected, the younger employees with a higher level of education ultimately agreed on the ease of using new technologies. Older employees with a lower level of education stated that there is great difficulty in using these systems.

The outcomes of this paper indicate that employees with prior knowledge of the use of similar applications and who are given less guidance appear to have high perceived self-efficacy. For intention to use, the majority of the respondents responded very positively because, with the integration of these new technologies in their daily lives, their use has become almost mandatory. Thus, the outcomes of this paper confirm the acceptance of $\mathrm{H} 4$.

Looking at previous studies, particularly a study done by [39] on the determinants that affect the acceptance of digital banking in Malaysia, it is seen that the main factor was perceived ease of use. The relationship between perceived usefulness and intention to use digital banking is not significant, as well as that between perceived self-efficacy and intention to use digital banking in this study. Ref [48] examined the use of Information Technologies and analyzed several TAM models by other researchers, published between 1980 and 2001. They concluded that perceived ease of use variables and usefulness are the two most valuable variables for model interpretation. Ref [40], in their study on the use of digital technologies, explored the positive relationship between perceived usefulness and perceived ease of use variables with intention to use digital banking. It was estimated that this relationship is mitigated as the level of user's experience and familiarity with systems is increased. In contrast, ref [55] concluded that, during the COVID-19 pandemic, perceived usefulness has an essential effect on the intention to use digital banking but perceived ease of use does not affect the choice to use digital banking. The outcomes of these studies can be characterized as an opportunity in the banking industry to promote policies to enhance the adoption of digital banking. The spread of COVID-19 can act as a significant determinant for providing applicable practices to formulate strategies to improve banking services, increase the acceptance of digital banking by employees and make changes to the traditional working processes $[56,57]$.

\section{Conclusions}

This article explored the attitude of banks' staff in Greece towards the digitalization of banking operations and their transition to the new digital banking environment. In recent 
years, Greek banks' employees have also changed their work, as a significant part of their work has been digitized. For this purpose, 161 bank employees participated in this study. As all Greek banks have entered a time of transition to digital banking, in the bid to cut operating costs and adopt a more flexible model of customer service, they need to take cognizance of their employees' attitudes towards this new development.

In an economic environment where many service sectors are pushed to search for innovative technological methods to serve their customers better and improve their internal processes [58-67], finding new business models with the digitalization of banking institutions' operations (digital transformation) is the most suitable process for the banking institutions of our country. Initially, this need was created for banks as they looked for ways to curb their operating expenses (reduction of physical stores and staff through voluntary exit programs), improve their internal processes and adopt a single way of working.

Although many people associate the digitization of jobs with job cuts, the results of the survey show that employees in Greek banks do not oppose the digital evolution of their work. It is seen that, on the one hand, workers accept the new data in the digital economy (entry of new alternative providers, e.g., viva wallet, opap wallet, N26, Revolut); on the other hand, there is an apparent risk of shrinking banking operations and intense banking competition in the domestic market. They do not leave much room for employees to oppose the new data [68-73]. This is reflected in the survey results, as the majority of the employees show that they accept the latest data, and it is not harmful to accept the new methods and practices of digital banking.

The most critical need in research is training on the usage of new technologies through training programs. Employees in Greek banks are not threatened by digital banking, but they need guidance and training on how to apply these new technologies. This is not only employees' perception. Such e-learning programs are now taking place in the banking sector in order to create a smooth transition to the new era; however, the question is, 'Will those employees who are not familiar with the new technologies and, who seem to have the greatest need to be taught how to use them, be given opportunities to go for training?' The lack of specialized human resources that have the appropriate skills to complete the transformation processes can cause delays in completing the projects. Also, the lack of non-automated processes that require human intervention can lead to the loss of data relevant to the operation of the bank, such as data about its relationships with customers.

In the recent agreement between the Union of Greek Banks and the Greek Federation of bank employee unions about the new working framework, one significant issue was the need to have people using new digital tools. Both sides agree that only through educational programs can employees enhance the positive effects of digitalization and overcome the fear of both sides about the upcoming transition. Digitalization creates new opportunities for development, however, there is a need for a smooth transition through training.

Another notable finding of this study is the rate at which employees are satisfied with their work. Employees in Greek banks seem to be generally satisfied with their work, especially in terms of their long-term employment prospects, as they do not see the risk of redundancies. Their most important concerns are related to remuneration policy, as they consider that there is a disproportion between wages and workload, the lack of prospects within the organization and, finally, their inability to apply their methods and practices in their work.

The cyber risk is a significant challenge that should be taken into consideration by employees and executives and may influence their intention to use digital technologies. Employees ignore the negative consequences of cyberattacks. Executives in the banking sector are concerned about the ability of banks to perceive, deal with and assess the risk of cyberattacks, as well as the power of regulators to perceive and act as a deterrent to systemic threats and attacks that directly affect the credibility of the financial system. The lack of adequately trained and specialized staff is a serious challenge. At the same time, internal risk and the lack of control procedures for new and existing staff are essential factors of operational and systemic risk. 
The above conclusions should be used by the human resources departments of the banks to stimulate the workers with their policies, to reduce their reservations against the digital transformation and to make the employees allies in order for them to deliver maximum results through the new development. Managers should promote the use of digitalization and remote working as a result of the COVID-19 outbreak.

The main contribution of our research is that, despite digital transformation being connected with unemployment and loss of income, employees in Greek banks have positive attitudes towards digitalization. If we considered only high level executives' views, it could be claimed that there is bias in the survey (present the most positive perception). By receiving answers at any level form all bank employees, we ensured that there are no biased results. Moreover, the second most crucial contribution is that there is a standard view (both among management and employees) that there is need for education and learning programs to increase the knowledge background of employees. This need also stems from their possible uncertainty about whether they will still have the skills to be efficient in the organization. The contribution of the top management will be addressing the need to reform their education programs and adjust them to the current needs of digital skills and usage of technology. All of these programs are even more crucial and meaningful nowadays, with the consequences of the COVID-19 pandemic.

There have also been some restrictions on the conduct of the survey. The questionnaires were distributed via electronic platforms and email. Therefore, the bank employees who could not use the above did not respond. In addition, a question about the employees' service bank was dropped so that no specific behavior and degree of employees' acceptance could be linked to a particular bank.

As technological developments are rapid and continuous in the banking sector, the researchers should consider the time spent on that study and the social data that may affect the judgment of an employee in the banking industry. Indicatively, at the time of the survey, several voluntary exit programs or violent exit programs (transfer of staff to an Intrum insecure claims management company) was in force, which may have adversely affected the attitude of the respondents towards technological development and its consequences.

Concerning the data of the questionnaire, and given the pace at which digitalization of banking has been established and expanded, future researchers should consider re-investigating the attitude of employees and the degree of their acceptance of new technologies. This should be done with employees who are not bothered about the negative impact that digital banking might have on them, such as losing their jobs, for them not to be prejudiced in their responses. In addition, the research could be extended to the newly established branch of Domestic Loans and Credit Management Companies, which is also supervised by the Bank of Greece and is an integral part of the old banking sector. Many of today's bank employees are expected to work in this sector.

Author Contributions: Conceptualization, F.K. and I.G.; methodology, F.K. and I.G.; validation, M.K.; formal analysis, M.K.; investigation, I.G.; resources, I.G.; data curation, M.K.; writing-original draft preparation, F.K., M.K. and I.G.; writing-review and editing, F.K. and M.K.; supervision, F.K.; project administration, F.K. All authors have read and agreed to the published version of the manuscript.

Funding: This research received no external funding.

Institutional Review Board Statement: Not applicable.

Informed Consent Statement: Not applicable.

Data Availability Statement: Data sharing not applicable.

Conflicts of Interest: The authors declare no conflict of interest. 


\section{References}

1. Deng, X.; Huang, Z.; Cheng, X. FinTech and Sustainable Development: Evidence from China Based on P2P Data. Sustainability 2019, 11, 6434. [CrossRef]

2. Shin, Y.J.; Choi, Y. Feasibility of the Fintech Industry as an Innovation Platform for Sustainable Economic Growth in Korea. Sustainability 2019, 11, 5351. [CrossRef]

3. PRESSE BOX. Available online: https://www.pressebox.com/pressrelease/gartner-uk-ltd/Gartner-Says-Worldwide-EnterpriseIT-Spending-is-Forecast-to-Grow-2-5-Per-Cent-in-2013/boxid/555441 (accessed on 5 June 2020).

4. Cziesla, T. A Literature Review on Digital Transformation in the Financial Service Industry. In Proceedings of the Bled eConference, Bled, Slovenia, 1-5 June 2014.

5. Vial, G. Understanding digital transformation: A review and a research agenda. J. Strateg. Inf. Syst. 2019, 28, 118-144. [CrossRef]

6. Yip, A.W.; Bocken, N.M. Sustainable business model archetypes for the banking industry. J. Clean. Prod. 2018, 174, 150-169. [CrossRef]

7. Giatsidis, I.; Kitsios, F.; Kamariotou, M. Digital Transformation and User Acceptance of Information Technology in the Banking Industry. In Proceedings of the 8th International Symposium and 30th National Conference on Operational Research, Patra, Greece, 16-18 May 2019.

8. Zhao, Q.; Tsai, P.H.; Wang, J.L. Improving financial service innovation strategies for enhancing China's banking industry competitive advantage during the fintech revolution: A Hybrid MCDM model. Sustainability 2019, 11, 1419. [CrossRef]

9. Moewes, T.; Puschmann, T.; Alt, R. Service-based Integration of IT-Innovations in Customer-Bank-Interaction. In Proceedings of the Internationale Tagung Wirtschaftsinformatik, Zurich, Switzerland, 16-18 February 2011.

10. Ananda, S.; Devesh, S.; Lawati, A.M.A. What factors drive the adoption of digital banking? An empirical study from the perspective of Omani retail banking. J. Financ. Serv. Mark. 2020, 25, 14-24. [CrossRef]

11. Boratyńska, K. Impact of digital transformation on value creation in Fintech Services: An innovative approach. J. Promot. Manag. 2019, 25, 631-639. [CrossRef]

12. Breidbach, C.F.; Keating, B.W.; Lim, C. Fintech: Research directions to explore the digital transformation of financial service systems. J. Serv. Theory Pract. 2019, 30, 79-102. [CrossRef]

13. Dratva, R. Is open banking driving the financial industry towards a true electronic market? Electron. Mark. 2020, 30, 65-67. [CrossRef]

14. Hrustek, N.Ž.; Mekovec, R.; Pihir, I. Developing and validating measurement instrument for various aspects of digital economy: E-commerce, E-banking, E-work and E-employment. Int. J. E-Serv. Mob. Appl. 2019, 11, 50-67. [CrossRef]

15. Khanboubi, F.; Boulmakoul, A. Digital transformation in the banking sector: Surveys exploration and analytics. Int. J. Inf. Syst. Chang. Manag. 2019, 11, 93-127. [CrossRef]

16. Panda, A. Interview with Dr Anil K. Khandelwal: Leading Transformation of a Public Sector Bank Through People Processes and Building Intangibles. South Asian J. Hum. Resour. Manag. 2020, 7, 135-143. [CrossRef]

17. Sibanda, W.; Ndiweni, E.; Boulkeroua, M.; Echchabi, A.; Ndlovu, T. Digital technology disruption on bank business models. Int. J. Bus. Perform. Manag. 2020, 21, 184-213. [CrossRef]

18. Talbot, D.; Ordonez-Ponce, E. Canadian banks' responses to COVID-19: A strategic positioning analysis. J. Sustain. Financ. Invest. 2020, in press. [CrossRef]

19. Prensky, M. Digital natives, digital immigrants part 2. Horizon 2001, 9, 1-6. [CrossRef]

20. Banker, R.; Chen, P.; Liu, F.; Ou, C. Business Value of IT in Commercial Banks. In Proceedings of the International Conference on Information Systems, Phoenix, AZ, USA, 15-18 December 2009.

21. De Oliveira Santini, F.; Ladeira, W.J.; Sampaio, C.H.; Perin, M.G. Online banking services: A meta-analytic review and assessment of the impact of antecedents and consequents on satisfaction. J. Financ. Serv. Mark. 2018, 23, 168-178. [CrossRef]

22. Sloboda, L.; Dunas, N.; Limański, A. Contemporary challenges and risks of retail banking development in Ukraine. Banks Bank Syst. 2018, 13, 88-97. [CrossRef]

23. Cantoni, F.; Rossignoli, C. New Distribution Models for Financial Services: The Italian Banks' Approach to the on Line Trading Development. J. Electron. Commer. Res. 2000, 1, 60-66.

24. Dufty, N.F.; Savery, L.K.; Soutar, G.N. Banking industry employees and technological change. Prometheus 1987, 5, 284-303. [CrossRef]

25. Brohman, M.K.; Copeland, D.G. Riverbank financial: Changing the role of information technology. J. Inf. Technol. 1999, 14, 287-293. [CrossRef]

26. Ahmed, F.; Qin, Y.; Aduamoah, M. Employee readiness for acceptance of decision support systems as a new technology in Ebusiness environments; A proposed research agenda. In Proceedings of the 7th International Conference on Industrial Technology and Management, ICITM 2018, Oxford, UK, 7-9 March 2018.

27. Anand, V.V.; Banu, C.V.; Rengarajan, V.; Thirumoorthy, G.; Rajkumar, V.; Madhumith, R. Employee engagement- a study with special reference to bank employees in rural areas. Indian J. Sci. Technol. 2016, 9, 1-8. [CrossRef]

28. Mishra, V.; Singh, V. Analyzing the gap in the adoption of Internet Banking Services: Managers' perspective. In Proceedings of the 2nd International Conference on Business and Information Management, ICBIM 2014, Durgapur, West Bengal India, India, 9-11 January 2014. 
29. Chemingui, H. Resistance, motivations, trust and intention to use mobile financial services. Int. J. Bank Mark. 2013, 31, 574-592. [CrossRef]

30. Scott, S.V.; Van Reenen, J.; Zachariadis, M. The long-term effect of digital innovation on bank performance: An empirical study of SWIFT adoption in financial services. Res. Policy 2017, 46, 984-1004. [CrossRef]

31. Currie, W.L.; Willcocks, L. The New Branch Columbus project at Royal Bank of Scotland: The implementation of large-scale business process re-engineering. J. Strateg. Inf. Syst. 1996, 5, 213-236. [CrossRef]

32. Angelopoulos, S.; Kitsios, F.; Babulac, E. From e to u: Towards an innovative digital era. In Heterogeneous Next Generation Networking: Innovations and Platform; Kotsopoulos, S., Ioannou, K., Eds.; IGI Global Publishing: Hershey, PA, USA, 2008; Volume 19, pp. 427-444.

33. Kitsios, F.; Kamariotou, M. Mapping New Service Development: A Review and Synthesis of Literature. Serv. Ind. J. 2020, 40, 682-704. [CrossRef]

34. Kitsios, F.; Kamariotou, M. Strategic Change Management in Public Sector Transformation: The Case of Middle Manager Leadership in Greece. In Proceedings of the British Academy of Management (BAAM) Conference 2017, Coventry, UK, 5-7 September 2017.

35. Kitsios, F.; Kamariotou, M. The impact of Information Technology and the alignment between business and service innovation strategy on service innovation performance. In Proceedings of the 3rd IEEE International Conference on Industrial Engineering, Management Science and Applications (ICIMSA 2016), Jeju Island, Korea, 23-26 May 2016.

36. Kitsios, F.; Angelopoulos, S.; Zannetopoulos, I. Innovation and e-government: An in depth overview on e-services. In Heterogeneous Next Generation Networking: Innovations and Platform; Kotsopoulos, S., Ioannou, K., Eds.; IGI Global Publishing: Hershey, PA, USA, 2008; Volume 18, pp. 415-426.

37. Ho, S.J.; Mallick, S.K. The impact of information technology on the banking industry. J. Oper. Res. Soc. 2010, 61, 211-221. [CrossRef]

38. Moslehpour, M.; Pham, V.K.; Wong, W.K.; Bilgiçli, İ. E-purchase intention of Taiwanese consumers: Sustainable mediation of perceived usefulness and perceived ease of use. Sustainability 2018, 10, 234. [CrossRef]

39. Suhaimi, A.I.H.; Bin Abu Hassan, M.S. Determinants of Branchless Digital Banking Acceptance Among Generation Y in Malaysia. In Proceedings of the 2018 IEEE Conference on E-Learning, e-Management and e-Services (IC3e), Langkawi, Malaysia, 21-22 November 2018.

40. Venkatesh, V.; Bala, H. Technology acceptance model 3 and a research agenda on interventions. Decis. Sci. 2008, 39, 273-315. [CrossRef]

41. Davis, F.D. User acceptance of information technology: System characteristics, user perceptions and behavioral impacts. Int. J. Man-Mach. Stud. 1993, 38, 475-487. [CrossRef]

42. Setia, P.; Venkatesh, V.; Joglekar, S. Leveraging digital technologies: How information quality leads to localized capabilities and customer service performance. MIS Q. 2013, 37, 565-590. [CrossRef]

43. Davis, F.D. Perceived usefulness, perceived ease of use, and user acceptance of information technology. MIS Q. 1989, 319-340. [CrossRef]

44. Davis, F.D.; Bagozzi, R.P.; Warshaw, P.R. User acceptance of computer technology: A comparison of two theoretical models. Manag. Sci. 1989, 35, 982-1003. [CrossRef]

45. Munoz-Leiva, F.; Climent-Climent, S.; Liébana-Cabanillas, F. Determinants of intention to use the mobile banking apps: An extension of the classic TAM model. Span. J. Mark.-ESIC 2017, 21, 25-38. [CrossRef]

46. Pikkarainen, T.; Pikkarainen, K.; Karjaluoto, H.; Pahnila, S. Consumer acceptance of online banking: An extension of the technology acceptance model. Internet Res. 2004, 14, 224-235. [CrossRef]

47. Amin, H.; Supinah, R.; Aris, M.M.; Baba, R. Receptiveness of mobile banking by Malaysian local customers in Sabah: An empirical investigation. J. Internet Bank. Commer. 2012, 17, 1-13. [CrossRef]

48. Legris, P.; Ingham, J.; Collerette, P. Why do people use information technology? A critical review of the technology acceptance model. Inf. Manag. 2003, 40, 191-204. [CrossRef]

49. Kachigan, S.K. Multivariate Statistical Analysis: A Conceptual Introduction, 2nd ed.; Radius Press: Santa Fe, NM, USA, 1991

50. Newkirk, H.E.; Lederer, A.L.; Srinivasan, C. Strategic information systems planning: Too little or too much? J. Strateg. Inf. Syst. 2003, 12, 201-228. [CrossRef]

51. Kitsios, F.; Kamariotou, M. Job satisfaction behind motivation: An empirical study in public health workers. Heliyon 2021, 7, e06857. [CrossRef] [PubMed]

52. Kamariotou, M.; Kitsios, F. How Managers Use Information Systems for Strategy Implementation in Agritourism SMEs. Information 2020, 11, 331. [CrossRef]

53. Kitsios, F.; Kamariotou, M. Strategizing Information Systems: An empirical analysis of IT Alignment and Success in SMEs. Computers 2019, 8, 74. [CrossRef]

54. Kitsios, F.; Kamariotou, M. Strategic IT Alignment and Business Performance in SMEs: An Empirical Investigation. In Business Information Systems Workshops, Springer LNBIP 373; Abramowicz, W., Corchuelo, R., Eds.; Springer Nature: Basingstoke, UK, 2019; Volume 373, pp. 113-123.

55. Sudarsono, H.; Nugrohowati, R.N.I.; Tumewang, Y.K. The effect of COVID-19 pandemic on the adoption of Internet banking in Indonesia: Islamic bank and conventional bank. J. Asian Financ. Econ. Bus. 2020, 7, 789-800. [CrossRef] 
56. Nasri, W. Acceptance of Internet Banking in Tunisian Banks: Evidence from Modified UTAUT Model. Int. J. E-Bus. Res. 2021, 17, 22-41. [CrossRef]

57. Shahabi, V.; Azar, A.; Razi, F.F.; Shams, M.F.F. Simulation of the effect of COVID-19 outbreak on the development of branchless banking in Iran: Case study of Resalat Qard-al-Hasan Bank. Rev. Behav. Financ. 2021, 13, 85-108. [CrossRef]

58. Kitsios, F.; Stefanakakis, S.; Kamariotou, M.; Dermentzoglou, L. E-service Evaluation: User Satisfaction Measurement and Implications in Health Sector. Comput. Stand. Interfaces J. 2019, 63, 16-26. [CrossRef]

59. Kitsios, F.; Kamariotou, M. Open Data Hackathons: An Innovative Strategy to Enhance Entrepreneurial Intention. Int. J. Innov. Sci. 2018, 10, 519-538. [CrossRef]

60. Kitsios, F.; Grigoroudis, E.; Giannikopoulos, K.; Doumpos, M.; Zopounidis, C. Strategic decision making using multicriteria analysis: New service development in Greek hotels. Int. J. Data Anal. Tech. Strateg. 2015, 7, 187-202. [CrossRef]

61. Kitsios, F.; Kamariotou, M. Service innovation process digitization: Areas for exploitation and exploration. J. Hosp. Tour. Technol. 2021, 12, 4-18. [CrossRef]

62. Kitsios, F.; Kamariotou, M. Critical success factors in service innovation strategies: An annotated bibliography on NSD. In Proceedings of the British Academy of Management (BAM) Conference 2016, Newcastle, UK, 6-8 September 2016.

63. Kitsios, F.; Kamariotou, M.; Talias, M. Corporate Sustainability Strategies and Decision Support Methods: A Bibliometric Analysis. Sustainability 2020, 12, 521. [CrossRef]

64. Kamariotou, M.; Kitsios, F. Critical Factors of Strategic Information Systems Planning Phases in SMEs. In Information Systems. EMCIS 2018. Lecture Notes in Business Information Processing; Themistocleous, M., Rupino da Cunha, P., Eds.; Springer: Cham, Switzerland, 2019; Volume 341, pp. 503-517.

65. Kitsios, F.; Kamariotou, M. Artificial Intelligence and Business Strategy towards Digital Transformation: A Research Agenda. Sustainability 2021, 13, 2025. [CrossRef]

66. Mitroulis, D.; Kitsios, F. Using multicriteria decision analysis to evaluate the effect of digital transformation on organizational performance: Evidence from Greek tourism SMEs. Int. J. Decis. Support Syst. 2019, 4, 143-158. [CrossRef]

67. Mitroulis, D.; Kitsios, F. Evaluating digital transformation strategies: A MCDA analysis of Greek tourism SMEs. In Proceedings of the 14th European Conference on Innovation and Entrepreneurship (ECIE19), Kalamata, Greece, 19-20 September 2019.

68. Casquejo, M.; Himang, C.; Ocampo, L.; Ancheta, R.; Himang, M.; Bongo, M. The Way of Expanding Technology AcceptanceOpen Innovation Dynamics. J. Open Innov. Technol. Mark. Complex. 2020, 6, 8. [CrossRef]

69. Lee, S.; Kwon, Y.; Quoc, N.N.; Danon, C.; Mehler, M.; Elm, K.; Bauret, R.; Cho, S. Red Queen Effect in German Bank Industry: Implication of Banking Digitalization for Open Innovation Dynamics. J. Open Innov. Technol. Mark. Complex. 2021, 7, 90. [CrossRef]

70. Peñarroya-Farell, M.; Miralles, F. Business Model Dynamics from Interaction with Open Innovation. J. Open Innov. Technol. Mark. Complex. 2021, 7, 81. [CrossRef]

71. Wu, B.; Gong, C. Impact of open innovation communities on enterprise innovation performance: A system dynamics perspective. Sustainability 2019, 11, 4794. [CrossRef]

72. Yun, J.J.; Park, K.; Hahm, S.D.; Kim, D. Basic income with high open innovation dynamics: The way to the entrepreneurial state. J. Open Innov. Technol. Mark. Complex. 2019, 5, 41. [CrossRef]

73. Yun, J.J.; Zhao, X.; Jung, K.; Yigitcanlar, T. The culture for open innovation dynamics. Sustainability 2020, 12, 5076. [CrossRef] 